\title{
Penentuan Daerah Prospek Logam Tanah Jarang di Pulau Singkep
}

\section{Determination of Rare Earth Elements Prospect Area in Singkep Island}

\author{
Ngadenin*, Adhika Junara Karunianto, Frederikus Dian Indrastomo \\ Pusat Teknologi Bahan Galian Nuklir - BATAN \\ J1. Lebak Bulus Raya No.9, Pasar Jumat, Jakarta, Indonesia, 12440 \\ *E-mail: ngadenin@batan.go.id
}

Naskah diterima: 9 April 2020, direvisi: 18 Mei 2020, disetujui: 20 Mei 2020

DOI: 10.17146/eksplorium.2020.41.1.5853

\begin{abstract}
ABSTRAK
Logam tanah jarang merupakan bahan stategis yang digunakan pada perangkat teknologi tinggi dan energi bersih. Di Indonesia logam tanah jarang terkandung dalam mineral monasit, zirkon, dan xenotim sebagai mineralmineral ikutan pada penambangan timah di zona granit jalur timah Kepulauan Riau hingga Bangka Belitung. Singkep merupakan salah satu wilayah potensial logam tanah jarang karena terletak pada zona granit jalur timah. Penelitian ini bertujuan untuk menentukan daerah prospek logam tanah jarang di Pulau Singkep. Metoda yang digunakan adalah pengambilan 25 sampel konsentrat dulang pada beberapa tailing bekas tambang timah di Pulau Singkep. Sampel diambil pada setiap formasi batuan yang ada di Pulau Singkep dari batuan berumur tua hingga batuan berumur muda berturut-turut adalah kuarsit Bukit Duabelas berumur Permo-Karbon, komplek malihan Persing berumur Permo-Karbon, granit Muncung berumur Trias, granit Tanjungbuku berumur Yura, endapan rawa dan aluvium berumur Holosen. Setiap sampel konsentrat dulang dibagi menjadi dua bagian untuk analisis kandungan logam tanah jarang dan analisis mineral butir. Dua puluh lima (25) sampel dianalisis kandungan logam tanah jarangnya dan 14 sampel dianalisis kandungan mineral butirnya. Hasil analisis kandungan logam tanah jarang dan mineral butir menunjukkan bahwa daerah prospek logam tanah jarang terletak pada beberapa tailing bekas tambang timah di wilayah formasi batuan granit Muncung. Kadar lanthanum tertinggi mencapai 20100 ppm, cerium 37100 ppm, yttrium 9872 ppm dan neodymium 2840 ppm di mineral monasit, zirkon dan alanit.
\end{abstract}

Kata kunci: logam tanah jarang, tailing, konsentrat dulang, Singkep

\begin{abstract}
Rare earth elements (REE) are strategic material used in high-tech and clean energy devices. In Indonesia, REE contained in monazite, zircon, and xenotime minerals as accessories minerals in tin mining located in the granite tin belt of Riau Islands to Bangka Belitung. Singkep is one of the potential areas of REE because its location is in the granite tin belt. The goal of the study is to determine the REE prospects in Singkep Island. The method used by taking 25 pan concentrated samples on some tailing ex tin mining on the Singkep island. These samples were taken from each rock formation on Singkep Island in sequence from older to younger rocks formation, respectively. They are Permian Carboniferous of Bukit Duabelas quartzites, Permian Carboniferous of Persing Metamorphic Rocks, Triassic Muncung granite, Jurassic Tanjungbuku granite, Holocene swamps deposits and alluvium. Each sample of pan concentrated is divided into two parts for REE content and grain mineral analysis. All 25 samples were analyzed for REE content, while only 14 samples for the grain mineral. The results of REE content and grain mineral analysis indicate that the REE prospect area located in the tailings ex tin mining in the rock formation of the Muncung granite area. The highest concentration of lanthanum reached 20100 ppm, cerium 37100 ppm, yttrium 9872 ppm, and neodymium 2840 ppm in monazite, zircon, and allanite.
\end{abstract}

Keywords: rare earth elements, tailings, pan concentrate, Singkep 


\section{PENDAHULUAN}

Kelompok Logam Tanah Jarang (LTJ) adalah kelompok lantanida yang terdiri dari 15 unsur pada tabel periodik unsur, dimulai dari lanthanum dengan nomor atom 57 sampai dengan lutetium dengan nomor atom 71. Berdasarkan berat atomnya, secara umum LTJ dibagi menjadi dua kelompok yaitu LTJ ringan (Light Rare Earth Elements / LREE) dan LTJ berat (Heavy Rare Earth Elements / HREE) seperti terlihat pada Tabel 1 [1]. Tidak seperti logam mulia, meskipun LTJ relatif melimpah di kerak bumi (Tabel 1) tetapi sedikit sekali yang terkonsentrasi sebagai cebakan bijih [2]. Beberapa unsur dalam kelompok LTJ seperti lanthanum, cerium, neodymium dan yttrium digunakan sebagai komponen dalam perangkat teknologi tinggi, termasuk ponsel pintar, kamera digital, hard disk komputer, lampu neon, lightemitting-diode (LED), televisi layar datar dan monitor komputer (Tabel 2) [3]. Dalam jumlah besar beberapa unsur LTJ digunakan dalam energi bersih dan teknologi pertahanan.

Pembentukan LTJ umumnya terjadi pada jenis batuan dan tatanan geologi tertentu. Konsentrasi LTJ di kerak bumi cukup melimpah tetapi jarang yang dijumpai dalam konsentrasi yang ekonomis. Cebakan LTJ yang ekonomis di dunia terutama terbentuk di empat lingkungan geologi yaitu dalam batuan karbonatit, batuan beku alkali, ion adsorption clay dan cebakan plaser timah monasitxenotim [4].

Batuan karbonatit merupakan cebakan LTJ terbesar di dunia dan merupakan tipe LTJ ringan. Karbonatit adalah batuan beku mengandung mineral karbonat $>50 \%$ sebagai mineral utamanya, umumnya kalsit dan dolomit [5]. Karbonatit memiliki konsentrasi LTJ tertinggi dari semua batuan beku. Karbonatit merupakan sumber utama LTJ ringan untuk dunia sejak tahun 1960-an hingga 2009 (Gambar 1).

Batuan beku alkali adalah batuan beku dengan komposisi logam alkali $\left(\mathrm{K}_{2} \mathrm{O}+\mathrm{Na}_{2} \mathrm{O}\right)$ lebih besar dibanding $\mathrm{SiO}_{2}$. Hasil penelitian LTJ pada batuan beku alkali di beberapa tempat telah menemukan konsentrasi LTJ yang cukup signifikan yaitu $0,3-2,6 \%$ dari jumlah LTJ oksida dan sering terdapat pengayaan LTJ berat.

Tabel 1. Kelimpahan logam tanah jarang di kerak bumi [1].

\begin{tabular}{lccc}
\hline \multicolumn{1}{c}{ Unsur } & Simbol & $\begin{array}{c}\text { No } \\
\text { Atom }\end{array}$ & $\begin{array}{c}\text { Konsentrasi di } \\
\text { Kerak Bumi } \\
\text { (ppm) }\end{array}$ \\
\hline Lanthanum & LTJ ringan (LREE) & \\
Cerium & $\mathrm{La}$ & 57 & 39 \\
Praseodymium & $\mathrm{Ce}$ & 58 & 66,5 \\
Neodymium & $\mathrm{Pr}$ & 59 & 9,2 \\
Samarium & $\mathrm{Nd}$ & 60 & 41,5 \\
Europium & $\mathrm{Sm}$ & 62 & 7,05 \\
Gadolinium & $\mathrm{Eu}$ & 63 & 2 \\
& $\mathrm{Gd}$ & 64 & 6,2 \\
Terbium & LTJ berat & (HREE) & \\
Dysprosium & $\mathrm{Tb}$ & 65 & 1,2 \\
Holmium & $\mathrm{Dy}$ & 66 & 5,2 \\
Erbium & $\mathrm{Ho}$ & 67 & 1,3 \\
Thulium & $\mathrm{Er}$ & 68 & 3,5 \\
Ytterbium & $\mathrm{Tm}$ & 69 & 0,52 \\
Lutetium & $\mathrm{Yb}$ & 70 & 3,2 \\
Yttrium & $\mathrm{Lu}$ & 71 & 0,8 \\
\hline & $\mathrm{Y}$ & 39 & 33 \\
\hline
\end{tabular}

Tabel 2. Kegunaan yttrium, lanthanum, cerium dan neodymium [3].

\begin{tabular}{cclc}
\hline No & Unsur & \multicolumn{2}{c}{ Kegunaan } \\
\hline 1. & Yttrium (Y) & $\begin{array}{l}\text { Layar televisi dan komputer, } \\
\text { lampu LED, obat kanker, bahan }\end{array}$ \\
& & campuran untuk meningkatkan \\
& & kekuatan bahan, katalis. \\
& & Lensa kamera, penerangan \\
2. Lanthanum & studio, proyektor, elektroda \\
& baterai.
\end{tabular}

3. Cerium Konverter katalis di mobil, (Ce) pewarna kaca, produksi baja, kilang minyak mentah.

4. Neodynium Magnet bertenaga tinggi, (Nd) mikrofon, turbin angin, mobil hybrid, laser. 


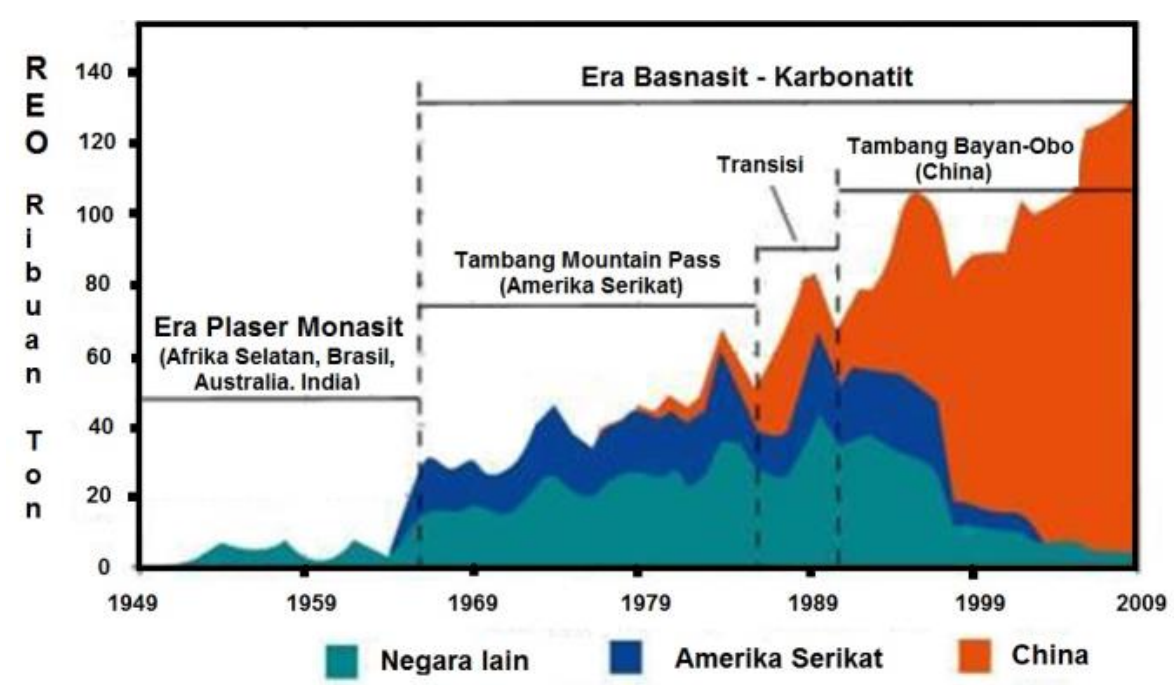

Gambar 1. Produksi LTJ Oksida Dunia [6].

Deposit LTJ pada ion adsorption clay atau lempung penyerap ion di Cina Selatan adalah sumber utama dunia untuk LTJ berat. Jenis cebakan ini secara informal disebut sebagai South China Clay. Kadar LTJ 0,04$0,25 \%$ dari jumlah LTJ oksida, terbentuk di daerah tropis dengan curah hujan sedang sampai tinggi. Meskipun konsentrasinya rendah, tetapi LTJ pada batulempung penyerap ion di Cina Selatan dianggap cukup ekonomis karena LTJ dapat dengan mudah diekstrak dari batulempung menggunakan asam lemah. Selain itu, pada cebakan ini sering terjadi pengayaan LTJ berat dan biaya tenaga kerja di Cina relatif rendah.

Deposit LTJ pada cebakan plaser timahmonasit-xenotim merupakan sumber LTJ penting sebelum pertengahan 1960-an (Gambar 1). Mineral monasit [(Ce,La,Th) $\left.\mathrm{PO}_{4}\right)$ ] dan xenotim $\left(\mathrm{YPO}_{4}\right)$ merupakan mineral ikutan pada cebakan plaser timah. Selain LTJ, di dalam monasit dan xenotim juga terdapat torium (Th) dan uranium (U) [4, 5] yang dapat dipergunakan sebagai bahan baku untuk pembuatan bahan bakar nuklir. Monasit merupakan mineral sumber cerium dan lanthanum sedangkan xenotim merupakan mineral sumber yttrium.
Daerah kepulauan Bangka-BelitungSingkep memiliki deposit LTJ sebagai cebakan plaser timah-monasit-xenotim. Daerah ini merupakan bagian dari sabuk granit Asia Tenggara yang mengandung timah [7]. Monasit dan xenotim merupakan mineral ikutan pada pertambangan timah plaser di daerah tersebut. Penambangan timah di Pulau Singkep sudah dimulai sejak jaman penjajahan Belanda yaitu sekitar tahun 1870 . Saat ini, tidak ada penambangan timah di Pulau Singkep, karena cadangan timahnya dianggap sudah habis. Pada saat penambangan timah, mineral monasit dan xenotim sebagai mineral ikutan tidak diambil karena dianggap belum mempunyai nilai ekonomis. Seiring dengan kemajuan teknologi industri, yang diawali oleh teknologi televisi berwarna yang booming pada tahun 1960-an di Amerika, maka pemanfaatan LTJ dalam berbagai bidang mulai ditingkatkan di dunia. Pada saat ini LTJ dimanfaatkan dalam berbagai bidang teknologi tinggi hingga mempunyai peran yang sangat penting di dunia.

Penelitian ini bertujuan untuk mengidentifikasi keterdapatan LTJ (cerium, lanthanum, neodymium dan yttrium) pada 
tailing bekas tambang timah di Pulau Singkep. Monasit dan xenotim sebagian besar terbuang pada saat proses penambangan timah dan tertinggal sebagai tailing tambang timah. Lokasi penelitian berada di seluruh wilayah Pulau Singkep yang secara administrasi termasuk ke dalam wilayah Kabupaten Lingga, Provinsi Kepulauan Riau.

\section{TATA KERJA}

Peralatan yang digunakan dalam penelitian ini adalah palu geologi, kompas geologi, kaca pembesar, Global Positioning System (GPS) navigasi, kamera, dulang tradisional, alat analisis unsur X-Ray Flouresence (XRF), gelas ukur, alat penghalus mineral (ball mill) dan alat pembuat pelet serta mikroskop binokuler.
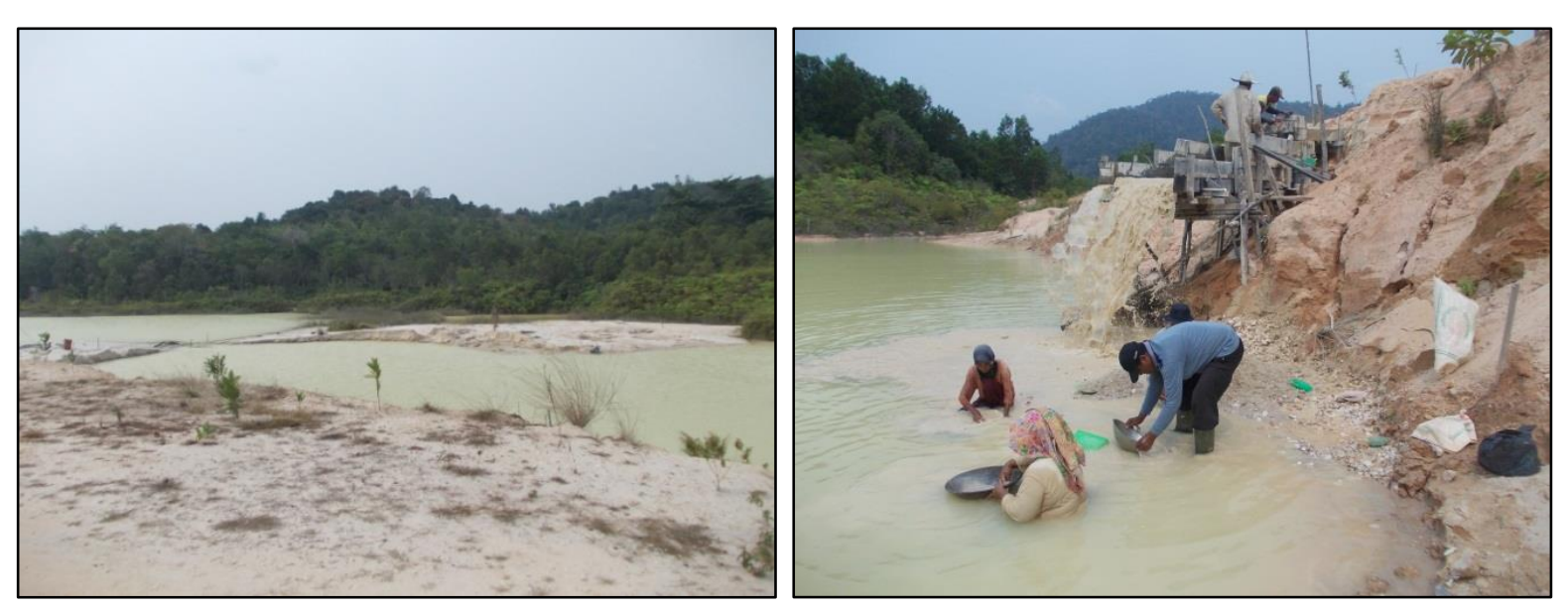

Gambar 2. Tailing pada lokasi bekas tambang timah di Singkep (kiri); pendulangan mineral berat pada tailing di bekas tambang (kanan).

Analisis unsur dan kadar LTJ menggunakan metode XRF. Sampel konsentrat dulang yang diperoleh dari lapangan dimasukkan ke dalam larutan tetrabromoethane untuk memperoleh mineral berat (berat jenis lebih besar 2,7). Mineral ringan yang mempunyai berat jenis kurang dari 2,7 akan mengambang dalam larutan tetrabromoethane dan mineral yang mempunyai berat jenis lebih dari 2,7, sehingga akan mengendap sebagai mineral

Bahan yang digunakan adalah bahan kimia untuk mengendapan mineral berat yaitu tetrabromoethane, bahan kimia untuk campuran pembuat pelet (cereox) dan konsentrat dulang.

Metode yang digunakan antara lain pengambilan sampel konsentrat dulang, analisis geokimia XRF, dan analisis mineralogi butir. Pengambilan sampel konsentrat dulang pada tailing di bekas tambang timah yang ada di Pulau Singkep dengan cara didulang secara tradisional (Gambar 2). Lokasi pengambilan sampel diplot dalam peta sesuai koordinat hasil pengukuran dengan GPS. Peta dasar yang digunakan yaitu peta geologi lembar Dabo, Sumatera skala 1: 250000. di 
untuk dianalisis unsur dan kadar LTJ. Analisis mineralogi dilakukan dengan cara pengamatan butiran mineral berat di bawah mikroskop binokuler sinar pantul.

\section{HASIL DAN PEMBAHASAN \\ Geologi Pulau Singkep}

Stratigrafi Pulau Singkep dari tua ke muda berturut-turut adalah kuarsit Bukit Duabelas berumur Permo-Karbon, komplek malihan Persing berumur Permo-Karbon, granit Muncung berumur Trias, granit Tanjungbuku berumur Yura, endapan rawa dan aluvium berumur Holosen [8] (Gambar 3). Kuarsit Bukit Duabelas terdiri dari kuarsit dengan sisipan filit dan batusabak. Komplek malihan Persing terdiri dari perselingan filit, batusabak dan sekis grafit dengan urat-urat kuarsa. Granit Muncung terdiri dari granit, diorit dan aplit. Granit Tanjungbuku terdiri dari granit dan diorit. Endapan rawa tersusun oleh lumpur, lempung dan gambut. Aluvium tersusun oleh material lepas berukuran kerikil, pasir, lempung dan lumpur.

Pulau Singkep merupakan bagian dari sabuk granit Asia Tenggara pembawa timah yang membentang dari utara ke selatan yaitu dari Myanmar, Thailand, Malaysia, Singapura, Kepulauan Riau dan Bangka Belitung. Granit tersebut terbagi dalam tiga jalur yaitu Jalur Utama, Jalur Barat dan Jalur Timur [7, 9, 10]. Cebakan timah di Pulau Singkep berkorelasi dengan granit pada Jalur Utama [11-15]. Mineral monasit ditemukan pada granit tipe-S [16-18] dan tipe-A [1921], sementara di granit tipe-I tidak ditemukan. Granit Muncung diklasifikasikan sebagai granit tipe-S, sementara Granit Tanjungbuku adalah tipe-I [7].

Ditinjau dari urutan stratigrafinya, cebakan LTJ yang berpotensi terbentuk di Pulau Singkep adalah cebakan LTJ tipe plaser timah-monasit-xenotim. Granit Muncung berperan sebagai batuan sumber. Rombakan batuan granitik ini kemudian terendapkan di sungai-sungai purba sebagai endapan aluvium sehingga menjadi perangkap atau wadah terakumulasinya endapan timah, monasit dan xenotim sebagai endapan sungai dan/atau pantai [22]. Sebaran Granit Muncung dapat ditemukan secara luas di barat laut Kota Dabo (Gambar 3).

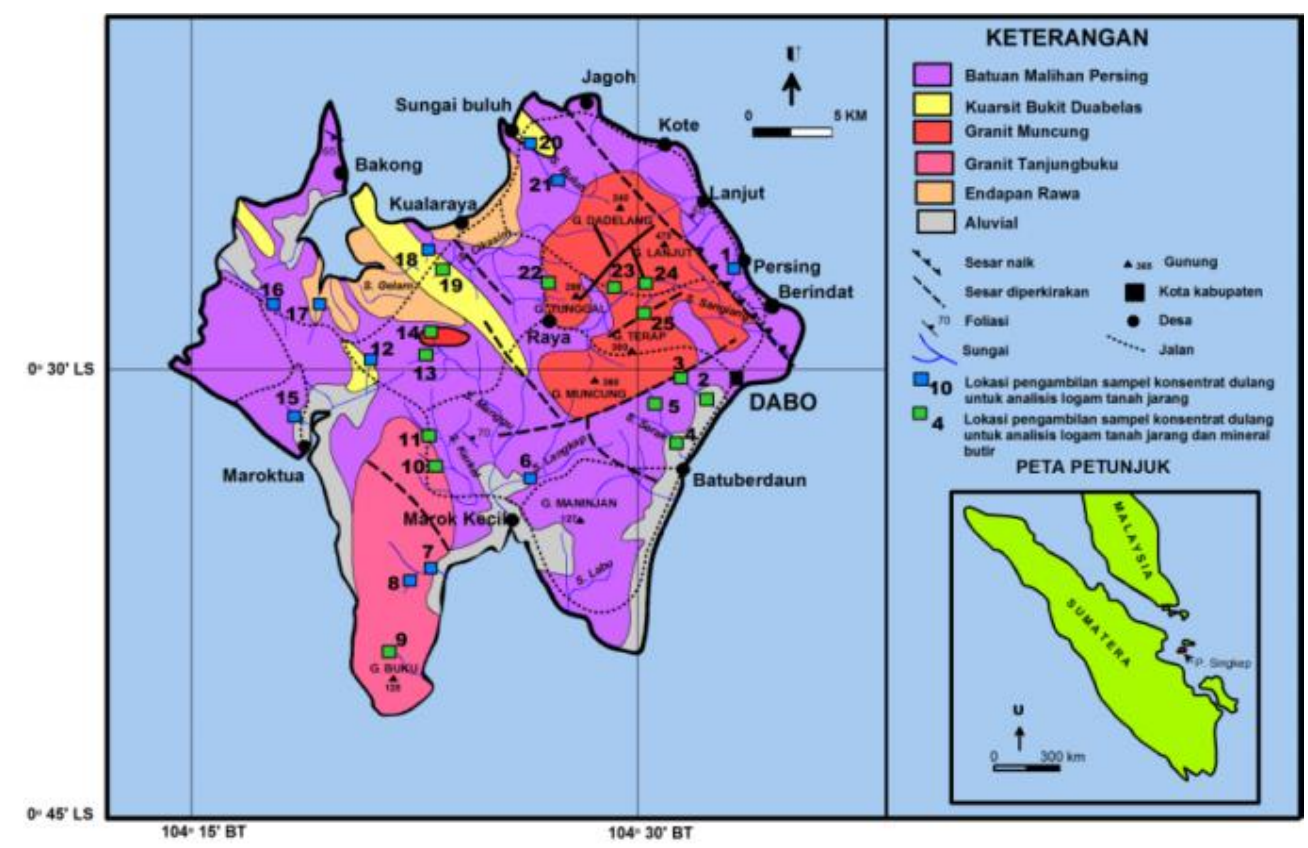

Gambar 3. Peta Geologi Pulau Singkep [8] dan Lokasi Pengambilan Sampel Konsentrat Dulang. 


\section{Analisis Kadar La, Ce, Nd dan Y}

Hasil analisis kadar lanthanum (La), cerium $(\mathrm{Ce})$, neodymium $(\mathrm{Nd})$ dan yttrium (Y) dari 25 sampel konsentrat dulang yang diambil dari lapangan memperlihatkan bahwa kadar La berkisar 32-20100 ppm, kadar Ce berkisar 35-37100 ppm, kadar Y berkisar 6,3-14000 ppm dan kadar Nd berkisar 1242840 ppm (Tabel 3). Secara umum kadar La, $\mathrm{Ce}, \mathrm{Nd}$ dan Y cukup tinggi bila dibandingkan dengan konsentrasi $\mathrm{La}, \mathrm{Ce}, \mathrm{Nd}$ dan $\mathrm{Y}$ dalam kerak bumi yaitu berturut-turut 39 ppm, 66,5 ppm, 41,5 ppm dan 33 ppm. Tingginya kadar
La, Ce, Nd dan Y diperkirakan berhubungan erat dengan keterdapatan mineral monasit, zirkon dan xenotim pada zona granit jalur timah [23]. Kehadiran Nd dalam hasil analisis LTJ diperkirakan adanya substitusi antara La dengan $\mathrm{Nd}$ atau Ce dengan $\mathrm{Nd}$ karena secara umum dalam monasit hanya terdapat La dan Ce [24]. Jika ditinjau dari wilayah formasi batuan lokasi pengambilan sampel konsentrat dulang maka kadar $\mathrm{La}, \mathrm{Ce}, \mathrm{Nd}$ dan $\mathrm{Y}$ tertinggi terdapat pada sampel-sampel yang diambil di wilayah batuan granit Muncung (Gambar 4).

Tabel 3. Hasil analisis kadar logam tanah jarang (ttd=tidak terdeteksi).

\begin{tabular}{lrrrrl}
\hline $\begin{array}{c}\text { No } \\
\text { Sampel }\end{array}$ & $\begin{array}{c}\text { La } \\
(\mathbf{p p m})\end{array}$ & $\begin{array}{c}\text { Ce } \\
(\mathbf{p p m})\end{array}$ & $\begin{array}{c}\text { Y } \\
(\mathbf{p p m})\end{array}$ & $\begin{array}{c}\text { Nd } \\
(\mathbf{p p m})\end{array}$ & \multicolumn{1}{c}{ Litologi } \\
\hline MB.01 & 1160 & 2175 & 444 & ttd & Batuan Malihan Persing \\
MB.02 & 383 & 830 & 583 & ttd & Aluvial \\
MB.03 & 2826 & 5557 & 6809 & ttd & Batuan Malihan Persing \\
MB.04 & 797 & 1652 & 3078 & 128 & Aluvial \\
MB.05 & 2012 & 3733 & 1134 & 593 & Batuan Malihan Persing \\
MB.06 & ttd & 47 & 6,3 & ttd & Batuan Malihan Persing \\
MB.07 & ttd & 35 & 58,9 & 413 & Granit Tanjungbuku \\
MB.08 & 33 & 100 & 406 & 124 & Granit Tanjungbuku \\
MB.09 & 32 & 77 & 1200 & ttd & Granit Tanjungbuku \\
MB.10 & 798 & 234 & 1705 & ttd & Granit Tanjungbuku \\
MB.11 & 830 & 166 & 3725 & ttd & Granit Tanjungbuku \\
MB.12 & 670 & 270 & 511 & ttd & Kuarsit Bukit Duabelas \\
MB.13 & 377 & ttd & 108 & ttd & Batuan Malihan Persing \\
MB.14 & 67 & ttd & 197 & ttd & Granit Muncung \\
MB.15 & ttd & 41 & 33,3 & 214 & Batuan Malihan Persing \\
MB.16 & 72 & ttd & 305 & ttd & Batuan Malihan Persing \\
MB.17 & 760 & 1380 & 356 & ttd & Endapan Rawa \\
MB.18 & 659 & 1153 & 68 & ttd & Kuarsit Bukit Duabelas \\
MB.19 & 7032 & 12900 & 14000 & ttd & Kuarsit Bukit Duabelas \\
MB.20 & 486 & 937 & 1364 & ttd & Kuarsit Bukit Duabelas \\
MB.21 & 1326 & 2397 & 1641 & ttd & Batuan Malihan Persing \\
MB.22 & 3196 & 6895 & 9872 & ttd & Granit Muncung \\
MB.23 & 4668 & 8781 & 2300 & 1228 & Granit Muncung \\
MB.24 & 18800 & 33600 & 7376 & 2840 & Granit Muncung \\
MB.25 & 20100 & 37100 & 8879 & 2376 & Granit Muncung \\
\hline
\end{tabular}

Kadar La tertinggi adalah 20100 ppm berasal dari hasil analisis sampel nomor MB.25. Kadar Ce tertinggi adalah 37100 ppm berasal dari hasil analisis sampel nomor MB.25. Kadar Nd tertinggi adalah 2840 ppm berasal dari hasil analisis sampel nomor MB.24. Kadar Y tertinggi adalah 14000 ppm berasal dari hasil analisis sampel nomor MB.19 (Tabel 3). Tingginya kadar La, Ce, Nd dan $\mathrm{Y}$ di wilayah granit Muncung sesuai 
dengan keterdapatan mineral-mineral radioaktif yang berpotensi terdapat LTJ yaitu mineral monasit, zirkon dan xenotim [25].

Kadar rata-rata layak tambang cebakan LTJ tipe plaser di Olserum Swedia adalah 6000 ppm [26]. Kadar rata-rata LTJ individu di wilayah granit Muncung secara umum melebihi kadar rata-rata cebakan LTJ di Olserum Swedia yang siap untuk ditambang (Gambar 4). Ditinjau dari kadarnya, maka LTJ yang terdapat pada tailing bekas tambang timah di wilayah sebaran batuan Granit Muncung layak untuk dikembangkan ke arah perhitungan sumber daya bahkan cadangan.

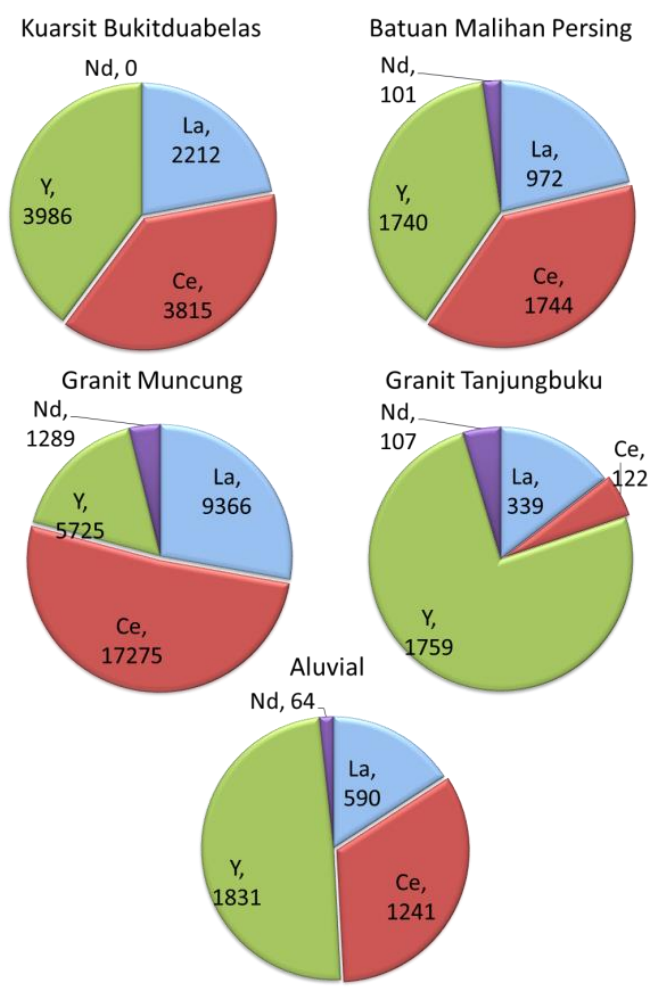

Gambar 4. Rerata kadar La, Ce, Nd dan Y (dalam ppm) hasil analisis XRF pada batuan dan aluvial di Singkep.

\section{Analisis Mineral Butir Konsentrat Dulang}

Hasil analisis butir dari 18 buah sampel konsentrat dulang yang diambil dari lapangan menunjukkan bahwa mineral yang terkandung dalam konsentrat dulang terdiri dari magnetit, hematit, ilmenit, monasit, zirkon, kasiterit, pirit, alanit, anatas, dan fluorit (Tabel 4).

Mineral-mineral yang berpotensi mengandung LTJ adalah monasit $(\mathrm{Ce}, \mathrm{La}, \mathrm{Th}) \mathrm{PO}_{4}$, xenotim $\left(\mathrm{YPO}_{4}\right)$ dan alanit $(\mathrm{Ce}, \mathrm{Ca}, \mathrm{Y})_{2}\left(\mathrm{Al}, \mathrm{Fe}^{3}\right)_{3}\left(\mathrm{SiO}_{4}\right)_{3} \mathrm{OH} \quad$ [22]. Hasil analisis butir konsentrat dulang secara umum menunjukkan bahwa mineral kasiterit, ilmenit, monasit dan zirkon lebih dominan dibandingkan mineral lainnya. Hal ini merupakan suatu gambaran bahwa cebakan yang ada pada tailing di Pulau Singkep adalah cebakan plaser timah. Kasiterit merupakan mineral utama sedangkan monasit, xenotim dan zirkon sebagai mineral radioaktif ikutan.

Fenomena cebakan plaser timah dengan kasiterit sebagai mineral utama sementara monasit dan zirkon sebagai mineral ikutan tercermin dari hasil analisis butir sampel nomor MB.02 yang diambil dari tambang rakyat masih aktif di lapangan. Komposisi mineral pada sampel konsentrat dulang sampel nomor MB.02 menunjukkan bahwa jumlah kasiterit 29,91\% sedangkan monasit $14,90 \%$ dan zirkon 11,25\%. Komposisi mineral seperti ini merupakan gambaran cebakan timah plaser di zona granit jalur timah dengan kasiterit sebagai mineral utama dan monasit serta zirkon hanya sebagai mineral ikutan.

Beberapa sampel seperti MB.22 dan MB.24 terlihat bahwa monasit dan zirkon lebih dominan dibanding kasiterit. Komposisi mineral sampel nomor MB.22 monasit $52,89 \%$, zirkon $17,21 \%$ sementara kasiterit hanya $1,57 \%$ dan sampel nomor MB.24 komposisi monasit 52,10\%, zirkon 23,74\% sementara kasiterit hanya 2,07\% (Tabel 4). Komposisi mineral tersebut tidak menggambarkan bahwa cebakan di daerah penelitian adalah cebakan timah justru cenderung sebagai cebakan plaser monasit. Fenomena tersebut disebabkan oleh sampel 
konsentrat dulang pada penelitian ini diambil pada lokasi tailing bekas tambang timah. Monasit dan zirkon tertinggal pada waktu penambangan timah karena penambangan dikonsentrasikan hanya mengambil kasiterit sehingga monasit terlihat lebih dominan.

Hasil analisis konsentrat dulang memperlihatkan bahwa di semua formasi, yaitu kuarsit Bukit Duabelas, batuan malihan Persing, granit Muncung, granit Tanjungbuku endapan rawa dan aluvial ditemukan mineral monasit dan zirkon (Tabel 4 dan Gambar 5). Konsentrasi monasit tinggi ditemukan pada granit Muncung, sementara zirkon pada granit Tanjungbuku. Alanit ditemukan sedikit hanya pada granit Muncung.

Tabel 4. Hasil Analisis Mineral Butir Sampel Konsentrat Dulang dalam \% berat (ttd=tidak terdeteksi).

\begin{tabular}{lrrrrrrrrrrr}
\hline $\begin{array}{c}\text { No } \\
\text { Sampel }\end{array}$ & Kasiterit & Monasit & Zirkon & Ilmenit & Magnetit & Hematit & Alanit & Pirit & Anatas & Fluorit & Litologi \\
\hline MB.02 & 29,91 & 14,90 & 11.25 & 23,67 & 1,65 & 13,92 & $\mathrm{ttd}$ & $\mathrm{ttd}$ & 4,70 & $\mathrm{ttd}$ & $\mathrm{ALV}$ \\
MB.04 & 6,71 & 21,01 & 15,63 & 48,21 & 0,49 & 0,95 & $\mathrm{ttd}$ & $\mathrm{ttd}$ & 6,99 & $\mathrm{ttd}$ & $\mathrm{ALV}$ \\
MB.03 & 32,31 & 16,58 & 19,31 & 30,09 & 0,22 & 0,13 & $\mathrm{ttd}$ & 0,23 & 0,96 & 0,17 & $\mathrm{BMP}$ \\
MB.05 & 25,89 & 35,84 & 5,66 & 29,82 & 0,67 & 0,30 & $\mathrm{ttd}$ & $\mathrm{ttd}$ & 1,83 & $\mathrm{ttd}$ & $\mathrm{BMP}$ \\
MB.13 & 2,06 & 3,86 & 51,73 & 34,24 & 0,55 & 7,57 & $\mathrm{ttd}$ & $\mathrm{ttd}$ & $\mathrm{ttd}$ & $\mathrm{ttd}$ & $\mathrm{BMP}$ \\
MB.09 & $\mathrm{ttd}$ & 13,08 & 40,24 & 45,88 & 0,61 & 0,19 & $\mathrm{ttd}$ & $\mathrm{ttd}$ & $\mathrm{ttd}$ & $\mathrm{ttd}$ & $\mathrm{GTB}$ \\
MB.10 & 13,44 & 5,86 & 60,81 & 19,01 & 0,40 & 0,48 & $\mathrm{ttd}$ & $\mathrm{ttd}$ & $\mathrm{ttd}$ & $\mathrm{ttd}$ & $\mathrm{GTB}$ \\
MB.11 & 4,46 & 1,40 & 66,44 & 12,46 & 0,17 & 0,16 & $\mathrm{ttd}$ & 14,91 & $\mathrm{ttd}$ & $\mathrm{ttd}$ & $\mathrm{GTB}$ \\
MB.14 & $\mathrm{ttd}$ & 0,43 & 48,26 & 48,12 & 1,09 & 2,10 & $\mathrm{ttd}$ & $\mathrm{ttd}$ & $\mathrm{ttd}$ & $\mathrm{ttd}$ & $\mathrm{GMC}$ \\
MB.22 & 1,57 & 52,89 & 17,21 & 20,55 & 0,33 & 0,33 & $\mathrm{ttd}$ & 6,57 & 0,56 & $\mathrm{ttd}$ & $\mathrm{GMC}$ \\
MB.23 & 0,80 & 42,09 & 29,51 & 27,44 & 0,08 & 0,08 & $\mathrm{ttd}$ & $\mathrm{ttd}$ & $\mathrm{ttd}$ & $\mathrm{ttd}$ & $\mathrm{GMC}$ \\
MB.24 & 2,07 & 52,10 & 23,74 & 20,36 & 0,24 & 0,41 & 0,71 & $\mathrm{ttd}$ & 0,38 & $\mathrm{ttd}$ & $\mathrm{GMC}$ \\
MB.25 & 9,14 & 61,24 & 11,65 & 15,82 & 0,47 & 0,10 & 1,57 & $\mathrm{ttd}$ & $\mathrm{ttd}$ & $\mathrm{ttd}$ & $\mathrm{GMC}$ \\
MB.19 & 12,46 & 35,95 & 20,61 & 28,96 & 0,46 & 0,22 & $\mathrm{ttd}$ & $\mathrm{ttd}$ & 1,13 & 0,22 & KBD \\
\hline Rerata & $\mathbf{1 0 , 0 6}$ & $\mathbf{2 5 , 5 2}$ & $\mathbf{3 0 , 1 5}$ & $\mathbf{2 8 , 9 0}$ & $\mathbf{0 , 5 3}$ & $\mathbf{1 , 9 2}$ & $\mathbf{0 , 1 6}$ & $\mathbf{1 , 5 5}$ & $\mathbf{1 , 1 8}$ & $\mathbf{0 , 0 3}$ & \\
\hline Kerd &
\end{tabular}

Keterangan: ALV=Aluvial; BMP=Batuan Malihan Persing; GTB=Granit Tanjungbuku; GMC=Granit Muncung; KBD=Kuarsit Bukit Duabelas.

Ditinjau dari kandungan mineral dalam konsentrat dulang maka konsentrat dulang yang diambil di wilayah granit Muncung dianggap paling potensial mengandung LTJ. Dalam konsentrat dulang tersebut banyak ditemukan mineral-mineral potensial yang mengandung LTJ lebih banyak jenisnya dibandingkan dengan konsentrat dulang dari formasi batuan lainnya. Mineral mengandung LTJ pada konsentrat dulang yang diambil di wilayah granit Muncung adalah monasit, zirkon dan alanit, sementara pada konsentrat dulang yang diambil di wilayah formasi batuan lainnya hanya terdapat monasit dan zirkon saja (Gambar 5).

Hasil analisis mineral butir tidak menemukan mineral xenotim. Hal ini dapat terjadi karena xenotim ikut terbuang pada saat pendulangan mineral berat. Selain dari xenotim, unsur yttrium juga ditemukan di mineral alanit.

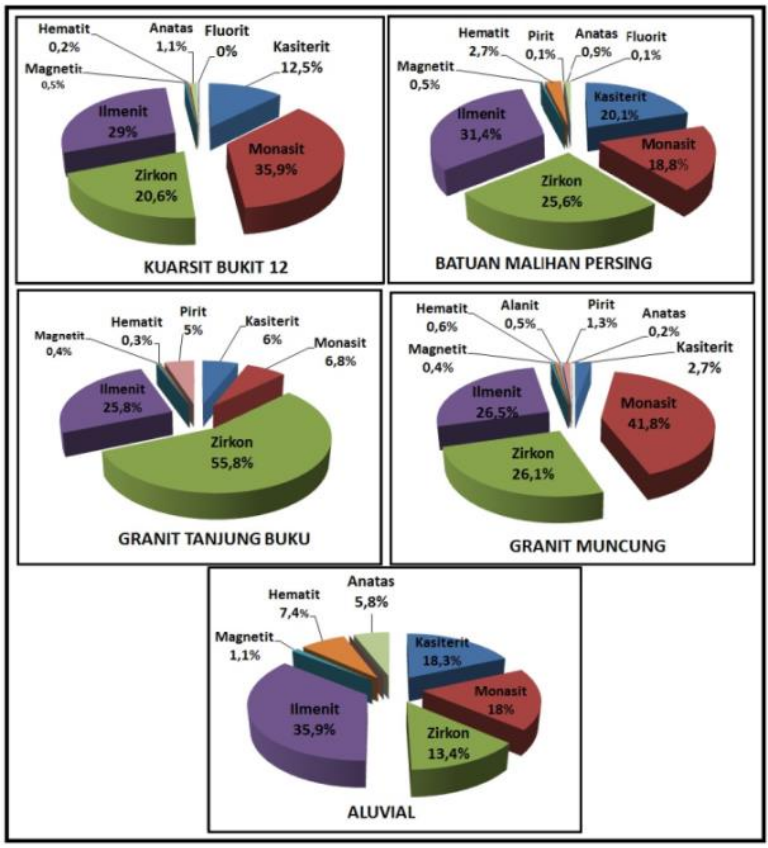

Gambar 5. Penyebaran mineral berat pada formasi batuan. 


\section{KESIMPULAN}

Konsentrasi unsur $\mathrm{La}, \mathrm{Ce}, \mathrm{Nd}$ dan $\mathrm{Y}$ sebagai unsur logam tanah jarang di daerah penelitian secara potensial berada di wilayah sebaran batuan granit Muncung dan aluvial hasil rombakannya. Sebarannya berada di bagian barat laut Kota Dabo. Saat ini, daerah tersebut merupakan bekas penambangan timah yang tailingnya masih mengandung unsur $\mathrm{La}, \mathrm{Ce}, \mathrm{Nd}$ dan $\mathrm{Y}$ di mineral monasit, zirkon dan alanit. Kadar La tertinggi mencapai 20100 ppm, Ce 37100 ppm, Nd 2840 ppm dan Y 9872 ppm. Depositnya ditemukan sebagai endapan aluvial hasil rombakan batuan granit tersebut. Pengukuran geolistrik dan pengeboran dapat diusulkan untuk penelitian selanjutnya sehingga sebaran dan ketebalan tailing diketahui dan jumlah potensi sumber dayanya dapat dihitung.

\section{UCAPAN TERIMA KASIH}

Pada kesempatan ini penulis menyampaikan banyak terimakasih kepada Bapak Ir. Yarianto Sugeng Budi Susilo, MSi sebagai Kepala Pusat Teknologi Bahan Galian Nuklir (PTBGN)-BATAN dan Bapak Heri Syaeful, MT sebagai Kepala Bidang Eksplorasi (PTBGN)-BATAN yang telah memberikan kesempatan dan dorongan moril kepada kami para penulis untuk melaksanakan penelitian ini sehingga penelitian dapat berjalan lancar sesuai dengan perencanaan. Tidak lupa penulis ucapkan terimakasih kepada teman-teman di laboratorium geokimia dan mineralogi yang telah membantu melakukan analisis kimia dan mineral.

\section{DAFTAR PUSTAKA}

[1] D. R. Lide, Ed., "Geophysics, Astronomy, and Acoustics," in CRC Handbook of Chemistry and Physics: A Ready-Reference of Chemical and Physical Data, 85th ed., Boca Raton, Fla: CRC Press, p. 14.17, 2004.
[2] K. R. Long, B. S. Van Gosen, N. K. Voley, dan D. Cordier, "The Principal Rare Earth Elements Deposits of the United States, USGS Scientific Investigations Report 2010-5220," 2010.

[3] T. Dutta, K. H. Kim, M. Uchimiya, E. E. Kwon, B. H. Jeon, A. Deeo, dan S. T. Yun "Global Demand for Rare Earth Resources and Strategies for Green Mining," Environmental Research., vol. 150, pp. 182-190, 2016, doi: 10.1016/j. envres.2016.05.052.

[4] N. Haque, A. Hughes, S. Lim, dan C. Vernon, "Rare Earth Elements: Overview of Mining, Mineralogy, Uses, Sustainability and Environmental Impact," Resources, vol. 3, no. 4 pp. 614-635, 2014.

[5] A. R. Chakhmouradian dan A. N. Zaitsev, "Rare Earth Mineralization in Igneous Rocks: Sources and Processes," Elements, vol. 8, no. 5, pp. 347353, 2012, doi: 10.2113/gselements.8.5.347.

[6] The Value Portfolio,"Russia - Rare Earth Element Production Will Grow." [Online]. Available: https://seekingalpha.com/article/3197746-russiarare-earth-element-production-will-grow. [Accessed: 20-Jun-2019].

[7] E. J. Cobbing, D. I. J. Mallick, P. E. J. Pitfield, dan L. H. Teoh, "The Granites of the Southeast Asia Tin Belt," Journal of the Geological Society London, vol. 143, pp. 537-550, 1986, doi: https://doi.org/10.1144/gsjgs.143.3.0537.

[8] K. Sutisna, G. Burhan, dan B. Hermanto, "Peta Geologi Lembar Dabo, Sumatera, Skala 1:250.000," Bandung: Pusat Penelitian dan Pengembangan Geologi, 1994.

[9] W. J. M. Court, M. J. Crow, E. J. Cobbing, dan T. C. Amin, "Mesozoic and Cenozoic Plutonic Evolution of SE Asia: Evidence from Sumatra, Indonesia," Geological Society of London, Special Pubications, vol. 106, pp. 321-335, 1996.

[10] M. O. Schwartz, S. S. Rajah, A. K. Askury, P. Putthapiban, dan S. Djaswadi, "The Southeast Asia Tin Belt," Earth-Science Reviews, vol. 38, pp. 95-293, 1995.

[11] S. Wai-Pang Ng, M. J. Whitehouse, M. P. Searle, L. J. Robb, A. A. Ghani, S. L. Chung, G. J. H. Oliver, M. Sone, N. J. Gardiner, dan M. H. Roselee, "Petrogenesis of Malaysian Granitoids in the Southeast Asian Tin Belt: Part 2. U-Pb Zircon Geochronology and Tectonic Model," Bulletin Geological Society America, vol. 127, no. 9-10, pp. 1238-1258, 2015, doi: 10.113 0/B31214.1.

[12] C. S. Hutchison, "Tectonic Evolution of Southeast Asia," Bulletin Geological Society Malaysia, vol. 60, no. December, pp. 1-18, 2014, doi: 10.7186/ bgsm60201401.

[13] N. J. Gardiner, J. P. Sykes, A. Trench, dan L. J. Robb, "Tin Mining in Myanmar: Production and Potential," Resources Policy, vol. 46, pp. 219 
233, 2015, doi: 10.1016/j.resourpol.2015.10.002.

[14] Ngadenin, H. Syaeful, K. S. Widana, dan M. Nurdin, "Potensi Thorium dan Uranium Di Kabupaten Bangka Barat," Eksplorium, vol. 35, no. 2, pp. 69-84, 2014.

[15] R. Irzon, "Contrasting Two Facies of Muncung Granite in Lingga Regency Using Major, Trace, and Rare Earth Element Geochemistry," Indonesian Journal of Geoscience., vol. 2, no. 1, pp. 23-33, 2015, doi: 10.17014/ijog.2.1.23-33.

[16] E. H. Christiansen and J. D. Keith, "Trace Element Systematics in Silicic Magmas: A Metallogeneic Prospective," Trace Element Geochemistry of Volcanic Rocks: Application of Massive Sulphide Exploration, Geological Association of Canada, Short Course Note, vol. 12, pp. 115-151, 1996.

[17] I. M. H. R. Antunes, A. M. R. Neiva, M. M. V. G. Silva, dan F. Corfu, "Geochemistry of S-type Granitic Rocks From the Reversely Zoned Castelo Branco Pluton (Central Portugal)," Lithos, vol. 103, no. 3-4, pp. 445-465, 2008, doi: 10.1016/j.lithos.2007.10.003.

[18] A. Imai, K. Sanematsu, S. Ishida, K. Watanabe, dan J. Boosayasak, "Rare Earth Elements in Weathered Crust in Sn-bearing Granitic Rocks in Southern Thailand," Proceedings of the International Symposium on Geoscience Resources and Environments of Asian Terranes (GREAT 2008), 4th IGCP 516 \& 5th APSEG Meeting, pp. 232-237, 2008.

[19] F. Colombo, R. Lira, dan M. J. Dorais, "Mineralogy and Crystal Chemistry of Micas from the A-type El Portezuelo Granite and Related Pegmatites, Catamarca (NW Argentina)," Journal of Geosciences., vol. 55, no. 1, pp. 4356, 2010, doi: 10.3190/jgeosci.058.

[20] L. S. Singh dan G. Vallinayagam, "High Heat Producing Volcano-Plutonic Rocks of the Siner Area, Malani Igneous Suite, Western Rajasthan,
India," Internatinal Journal of Geosciences, vol. 03, no. 05, pp. 1137-1141, 2012, doi: 10.4236 /ijg.2012.35115.

[21] D. Majumdar dan P. Dutta, "Rare Earth Element Abundances in Some A-type Pan-African Granitoids of Karbi Hills, North East India," Current Science, vol. 107, no. 12, pp. 2023-2028, 2014, doi: 10.18520/cs/v107/i12/2023-2029.

[22] A. R. Chakhmouradian dan F. Wall, "Rare Earth Elements: Minerals, Mines, Magnets (and more)," Elements, vol. 8, no. 5, pp. 333-340, 2012, doi: 10.2113/gselements.8.5.333.

[23] E. Suwargi, B. Pardiarto, dan T. Ishlah, "Potensi Logam Tanah Jarang di Indonesia," Buletin Sumber Daya Geologi., vol. 5, pp. 131-140, 2010.

[24] A. El-Taher, "Elemental Analysis of Granite by Instrumental Neutron Activation Analysis (INAA) and X-ray Fluorescence Analysis (XRF)," Applied Radiation and Isotopes, vol. 70, no. 1, pp. 350-354, 2012, doi: 10.1016 /j.apradiso.2011.09.008.

[25] Ngadenin dan A. J. Karunianto, "Identifikasi Keterdapatan Mineral Radioaktif pada Granit Muncung Sebagai Tahap Awal untuk Penilaian Prospek Uranium dan Thorium di Pulau Singkep," Eksplorium, vol. 37, no. 2, p. 63, 2016, doi: 10.17146/eksplorium.2016.37.2.3101.

[26] K. M. Goodenough, J. Schilling, E. Jonsson, P. Kalvig, N. Charles, J. Tuduri, E. A. Deady, M. Sadeghi, H. Schiellerup, A. Muller, G. Bertrand, N. Arvanitidis, D. G. Eliopoulos, R. A. Shaw, K. Tharene, dan N. Keulen 'Europe's Rare Earth Element Resource Potential: An Overview of REE Metallogenetic Provinces and Their Geodynamic Setting," Ore Geol. Rev., vol. 72, pp. 838-856, 2016, doi: 10.1016/j.oregeorev. 2015.09.019. 